\title{
Review a legacy resource: a new feature in MSOR Connections to aid discovery of hidden gems
}

Peter Rowlett, Department of Engineering and Mathematics, Sheffield Hallam University, Sheffield, U.K. Email: p.rowlett@shu.ac.uk

\section{Call for contributions}

Over recent decades, our community has operated numerous projects and produced countless resources. Certainly some of these were of their time and are now of limited value, but many still offer huge potential for those engaged with teaching, learning, assessment and support in higher education mathematics, statistics and OR. However, projects that are no longer running may not be in a position to advertise their resources, so how will people discover them?

The issue of how these resources might be discovered has come to mind again recently as I engage with a sigma Network project around storage and use of legacy resources (operating under the working title 'Mathcentre 2.0'). I write to propose a new feature in MSOR Connections that would offer short reviews of legacy resources. These could be resources for use with students or teaching practice guides. The aim is to shine a light on little-used, perhaps-forgotten but good-quality resources produced under now-defunct projects.

Do you have a favourite resource that fits the label 'legacy resource'? Please consider writing a review of it, to help others discover and use this. We will gladly accept contributions on these lines for MSOR Connections through the usual route (see the journal website* for details).

The remainder of this article offers a little history of the sort of projects and initiatives in the UK that I am thinking about. The intention is for this to be indicative, and not to be a restrictive list of projects and initiatives that are in the scope of what I am suggesting you might review.

\section{A little history}

The Maths, Stats and OR (MSOR) Network was formed in 2000, a kind of merger of the Computers in Teaching Initiative (CTI) Centres for Mathematics (at Birmingham) and Statistics (at Glasgow) and the Mathwise project, along with some higher education activity from the Royal Statistical Society Centre for Statistical Education (Blake, 2012). Initially part of the Learning and Teaching Support Network (LTSN), the MSOR Network later became part of the Higher Education Academy (HEA) before the HEA closed its 24 subject centres in 2012. As I write this, there is an archive of the MSOR Network website at the time of its closure available ${ }^{\dagger}$. This includes:

- $\quad$ an archive of 38 funded mini-projects which delivered their outputs between 2001 and 2011;

- articles from MSOR Connections volumes 1-12, published between 2001-12, as well as socalled 'volume 0', a newsletter called Maths, Stats \& OR published in 2000;

- proceedings from CETL-MSOR Conferences 2006-11;

* https://journals.gre.ac.uk/index.php/msor/

$\dagger^{\dagger}$ http://www.icse.xyz/mathstore/ 
- 59 articles in the maths-caa-series, which focused on developments in mathematics computer-aided assessment, published between 2001-6;

- leaflets, booklets and books published by various initiatives.

Some content from the MSOR Network is also available via the Higher Education Academy website. This contains another archive of MSOR Connections, this one including volume 13. Though I don't believe there is an index, so you can only really find resources there if you know what you are looking for. It may be worth noting that when I did an audit comparing my print copies of MSOR Connections to these two archives in 2015, I found that neither is a complete archive, they don't match each other and neither is a subset of the other, which I cannot explain.

In response to "the mathematics problem" (that incoming undergraduates might be "under-prepared for the mathematical demands of university courses") in the 1990s, universities began setting up mathematics support provision (Croft and Lawson, 2017; p. 196). In 2002, the universities of Loughborough, Coventry and Leeds gained funding to establish mathcentre (Croft and Lawson), joined by statstutor ${ }^{\dagger}$ in 2010 (Owen et al., 2010). In 2005, Loughborough and Coventry were funded to establish 'sigma - Centre for Excellence in University-wide Mathematics and Statistics support', later developed under the National HE STEM Programme and direct HEFCE funding into the sigma Network for Excellent in Mathematics and Statistics Support, now a volunteer-led professional association (Croft and Lawson). There are equivalent organisations to sigma in the Irish Mathematics Learning Support Network (IMLSN), formed in 2009, and the Scottish Mathematics Support Network (SMSN), formed in 2008 (Ahmed, 2018).

The other mathematics and statistics Centre for Excellence in Teaching and Learning (CETL) projects alongside sigma were the Postgraduate Statistics Centre at Lancaster and the Centre for Open Learning of Mathematics, Science, Computing and Technology (COLMSCT) at the Open University (Lawson, 2012).

The Undergraduate Mathematics Teaching Conference (formerly University Teaching Conference) started in 1975 (Emery, 2000) and ran in 2007 (Challis, 2007), I believe for the last time. This included a collection of working groups each year which produced numerous papers on different themes relevant to undergraduate teaching published in its proceedings.

As well as the sigma Network, the National HE STEM Programme (2010-12), following on from More Maths Grads (2007-9), funded various projects, including through the Institute of Mathematics and its Applications and the MSOR Network. I coordinated the work under the MSOR Network, which we called the Mathematical Sciences HE Curriculum Innovation Project (Rowlett, 2012). An archive of HE STEM activity and outputs has been established at the University of Birmingham ${ }^{\ddagger}$.

\footnotetext{
* http://www.mathcentre.ac.uk

${ }^{\dagger}$ http://www.statstutor.ac.uk

¥ https://www.birmingham.ac.uk/university/colleges/eps/STEM/National-HE-STEM-Programme/national-hestem-programme.aspx
} 
There are surely other initiatives and projects I have overlooked here but which may be considered valuable contributions by our community, but hopefully I have given a glimpse of the range of activity that might be investigated by those looking for hidden gems.

\section{References}

Ahmed, S., Davidson, P., Durkacz, K., Macdonald, C., Richard, M. and Walker, A., 2018. The Provision of Mathematics and Statistics Support in Scottish Higher Education Institutions (2017) - A Comparative Study by the Scottish Mathematics Support Network. MSOR Connections, 16(3), pp. 5-19.

Blake, J., 2012. Reflections from a past Director (2000-8). MSOR Connections, 12(2), pp. 34-35.

Challis, N., 2007. Undergraduate Mathematics Teaching Conference UMTC 17-18 December 2007. MSOR Connections, 7(3), p. 47.

Emery, D.J., 2000. Introduction. In: D. Emery, ed. Undergraduate Mathematics Teaching Conference 2000: Proceedings of the Twenty Sixth Conference, 4th-7th September 2000. Sheffield: Sheffield Hallam University Press. pp. 3-5.

Lawson, D., 2012. How things have changed: A personal reflection on the last 25 years. MSOR Connections, 12(2), pp. 9-11.

Lawson, D. and Croft, T., 2017. Improving Mathematics Education: what can we learn from 25 years of mathematics support? Mathematics Today, 53(5), pp. 196-199.

Owen, A., Green, D., Petrie, M., Davies, N. and Marriott, J., 2010. StatsTutor: An online statistics learning and teaching resource. In: C. Reading, ed. Data and context in statistics education: Towards an evidence-based society. Proceedings of the Eighth International Conference on Teaching Statistics (ICOTS8), Ljubljana, Slovenia, July 2010. Voorburg, The Netherlands: International Statistical Institute. Available at: http://iaseweb.org/documents/papers/icots8/ICOTS8 C198 OWEN.pdf [Accessed 27 March 2018].

Rowlett, P. (ed.), 2012. Summary of work in mathematical sciences HE curriculum innovation. Birmingham, U.K.: Maths, Stats and OR Network. Available at: http://mathcentre.ac.uk/resources/uploaded/hestemoverview.pdf [Accessed 27 March 2018]. 